\title{
NILAI GAMELAN: PENDEKATAN ETNOMUSICOSAINSLOGI
}

\author{
Ketut Sumerjana \\ Jurusan Musik ISI Denpasar \\ Email : Sumerjana@gmail.com
}

\begin{abstract}
Abstrak
Gamelandapat dipahami dari dua perspektif baik secara umum ataupun khusus, tinjauan khusus memposisikan bahwa nilai gamelan merupakan wilayah karawitan tetapi secara umum gamelan dapat dikategorikan dalam tataran bidang ilmu pengetahuan seperti etnomusikologi, fisika, matematika bahkan ilmu lainnya. Hadirnya dualisme perspektif sebenarnya secara harfiah mampu memberikan peluang untuk mengkontruksi sebuah pemikiran mengenai pengembangan pendekatan terhadap gamelan dalam konteks ilmu pengetahuan teknologi tanpa melupakan jati dirinya.

Kompleksitas nilai gamelan menuntun penelitian ini menggunakan metode komparasi yaitu membandingkan elemen intramusikal baik akustik maupun organologinya dengan ekstramusikal untuk dilakukan telaah secara mendalam sehingga nantinya dapat dijelaskan secara naratif.

Hasil penelitian menunjukkan bahwa nilai gamelan berisi konsep kecerdasan lokal jenius dalam mentransformasikan kompleksitas ilmu pengetahuan dan teknologi dalam intra musikalnya yang harus dipahami dan ditelaah dari berbagai disiplin ilmu pengetahuan.
\end{abstract}

Keyword: nilai, gamelan, etnomusicosainslogi

\begin{abstract}
Gamelan can be understood from two perspectives in general or specifically, a special review positions the value of gamelan as a musical area but in general gamelan can be categorized at the level of scientific fields such as ethnomusicology, physics, mathematics and even other sciences. The presence of perspective dualism is literally able to provide an opportunity to construct a thought about developing an approach to gamelan in the context of technological science without forgetting its identity.

The complexity of gamelan values guides this study using the comparative method of comparing intramusical elements, both acoustic and organological to extramusical, to be analyzed in depth so that later they can be explained narratively.

The results showed that the value of gamelan contains the concept of genius local intelligence in transforming the complexity of science and technology in its intra-music which must be understood and studied from various scientific disciplines.
\end{abstract}

Keyword: value, gamelan, etnomusicosainslogi 


\section{Pendahuluan}

Gamelan merupakan instrumen musik tradisi yang sampai saat ini masih mempunyai daya tarik, mempunyai nilai yang kompleks karena unsur intra-ekstra musikal. Kompleksitasgamelan terlihat dari kemampuan elemen pengkontruksinya mempunyai hubungan kausalitas, saling mengisi dan mampu menembus batasan ilmu pengetahuan, tidak hanya pada ilmu seni musik saja tetapi juga ilmu pengetahuan yang lain. Hal ini terbukti ketika membicarakan gamelan sebagai sebuah musik etnis ataupun karawitan maka tidak bisa serta merta melepas esensinya yaitu nilai yang ada di dalamnya sehingga memberikan sebuah pesan bahwa memahami sebuah musik harus luwes, tidak boleh kaku.

Nilai daya tarik, kompleksitas dan karakter gamelan ini sebenarnya secara harfiah bisa dikategorikan yang bernilai adiluhung berlandaskan kearifan lokal jenius. Relasi nilai pengetahuan merupakan tanda non fisik yang memberikan maksud bahwa dalam pendekatan memahami gamelan sebagai konsep-produk musik tidak hanya bisa terbatas pada dirinya sebagai seni musik, namun unsur jati dirinya harus digarap dengan merelasikan ilmu pengetahuan teknologi tanpa melupakan akarnya, seperti musik gamelan sebagai konsep atau teori, bahkan musik gamelan sebagai perilaku masyarakat seperti yang disampaikan oleh Meriam (1964: 232)

Perkembangan kajian gamelan seharusnya melandasi konsep pemikiran atau mindset yang ideal bahwa gamelan mampu memposisikan diri sebagai sebuah obyek material. Martopangrawit (dalam Becker; Freisten ed: 1984) menjelaskan bahwa konsep karawitan mempunyai jangkauan yang luas, tetapi sering juga dihubungkan dengan sistem gending. Martopangrawit menambahkan bahwa karawitan merupakan seni memproduksi suara dengan menggunakan konsep slendro danpelog. Uraian ini menandakan bahwa membicarakan karawitan sebagai musik bukan perkara yang mudah, karena pada umumnya tanda karawitan sebagai musik berposisi sebagai indek karena elemen yang mengkontruksinya mempunyai hubungan sebab-akibat sehingga saling mengisi dalam membentuk konsep-produk ilmu pengetahuan tekonologi yang berbasis kearifan lokal jenius. Konsep karawitan sebagai musik mempunyaimaknabahwa ilmu pengetahuan di dalamnya bergerak dinamis mencari sebuah titik ruang yang 
dapat merepresentasikan jati dirinya. Sedangkan sebagai produk, fisik nyatanya mampu diamati melalui sifat kuantumnya oleh tataran panca indera.

\section{Nilai}

Nilai merupakan sesuatu yang menarik bagimanusia, sebagaai sesuatu yang manusia cari, bersifat menyenangkan, sesuatu yangdisukai dan diinginkan, singkatnya nilai adalah sesuatu yang baik. Nilaiselalu mempunyai konotasi positif pada sesuatu yang manusia iya-kan atau manuiaaminkan (Bertens, 2013: 111). Nilai adalah segala hal yang berhubungan dengantingkah laku manusia mengenai baik atau buruk yang diukur oleh agama, tradisi,etika, moral, dan kebudayaan yang berlaku dalam masyarakat (Zakiyah danRusdiana, 2014: 15).

Nilai adalah sesuatu yang penting untuk kehidupan seseorang dan sesuatu yangdianggapnya layak untuk dimiliki oleh manusia. Berdasarkan definisi nilai daribeberapa pendapat tersebut dapat disimpulkan bahwa nilai sebagai sifat yang palingmendasar atau pokok dari manusia dan merupakan bagian dari ciri kepribadiansuatu manusia yang dapat menentukan sikap dan pendapat manusia dalammemahami perspektif dan kepentingan di luar diri sendiri.
Pierce (1931) memberikan pernyataan tentang tanda sebagai sesuatu yang mempunyai makna, berbentuk fisik yang dapat di tangkap oleh panca indera dan merupakan sesuatu yang merujuk atau merepresentasikan hal lain di luar tanda itu sendiri. Konsep tanda yang ditawarkan Pierce mengandung tiga hal yang penting yaitu makna, fisik, dan representasi tanda. Dalam upaya menjelaskan tanda, Pierce membagi tanda menjadi tiga yaitusimbol, ikon dan indeks. Simbol merupakan tanda yang muncul dari kesepakatan, ikon adalah perwakilan fisik dan indeks merupakan tanda yang muncul dari hubungan sebab akibat.

Pierce menambahkan bahwa dalam upaya menjelaskan tanda, bergantung pada konsep obyek yang menjadi referensi atau sesuatu yang dirujuk oleh tanda dan intepretan sebagai sebuah konsep pemikiran dari orang yang menggunakan tanda dan menurunkannya ke suatu makna tertentu atau makna yang ada dalam benak seseorang tentang obyek yang diturunkan sehingga terjadi sebuah proses semiosis. Uraian Pierce mengenai tanda 


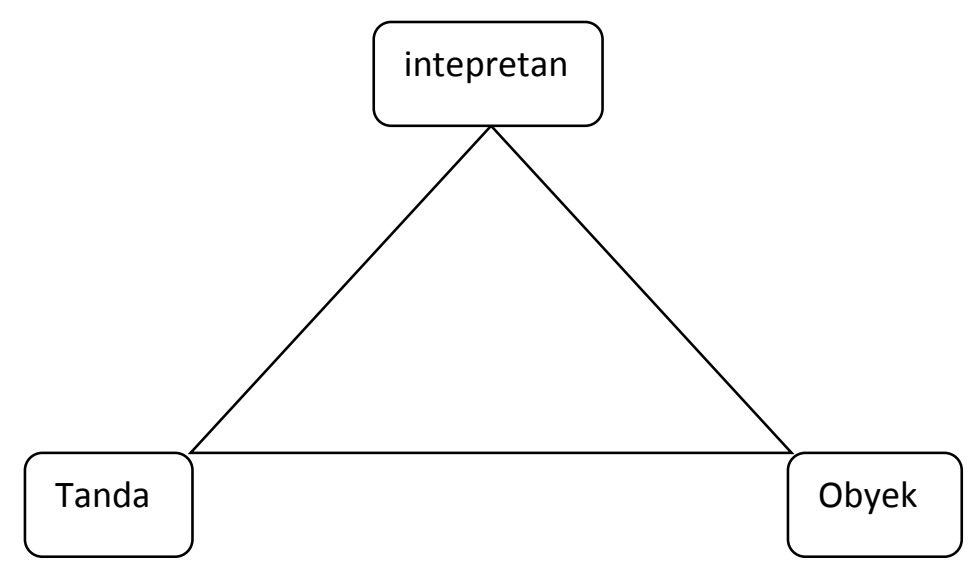

Gambar 1

Segitiga makna Pierce (dalam Chistomy : 2004)

Teori tentang semiotika Pierce tentang tanda memberikan kontribusi pada gagasan teori yang dinyatakan oleh Nattiez (1990) dalam sebuah tataran semiologi, yang memberikan sebuah penjelasan bahwa semiologi merupakan sebuah ilmu yang mempelajari suatu peran karya seni, terutama musik bekerja di dalam aktivitas masyarakat. Untuk dapat memahami semiologi Nattiez, maka terdapat dalam mengkaji sebuah musik pada tiga tataran ilmu pengetahuanyaitu pada tataran fisika, sejarah atau antropologi dan psikologi. Pada tataran pertama pemahaman semiologi mempergunakan kajian ilmu fisika dimana penguraian komponen-komponen yang mengkontruksi musik yaitu bunyi. Bunyi dikontruksi dari unsur-unsur seperti frekuensi, amplitude yang merupakan ranah kajian fisika.

Dalam tataran kedua adalah kajian sejarah, hal ini tidak bisa lepas dari sebuah prinsip kausalitas dimana ada sebab pasti ada akibat begitu pula adanya musik tidak serta merta lahir begitu saja, melainkan melalui sebuah proses yang rumit dan panjang. Sedangkan tahap ketiga adalah tataran psikologi, dimana sistem persepsi, kognisi dipergunakan dalam menelaah apa yang dirasakan oleh sistem fisiologi-biologi makhluk hidup.

Kompleksitas dan relasi tanda pada karawitan memberikan sebuah landasan untuk menggunakan metode komparasi dengan memperbandingkan dua aspek yang dikaji yaitu karawitan sebagai konsep musik dan karawitan sebagai produk musik yang berisikan ilmu pengetahuan teknologi berbasis kearifan lokal. Penggunaan metode komparasi dipilih karena dalam adanya relasi dari kompleksitas ilmu pengetahuan teknologi yang mengkontruksi karawitan berdasarkan unsur bunyi merupakan indek dari karawitan dan elemennya. 


\section{Metode Penelitian}

Metode ini menggunakan kualitatif naratif mengadaptasi dari Creswell (2012) yaitu mencoba mengintepretasikan pesan yang ingin disampaikan melalui audio-visual, komponen intra-ekstramusikal sehingga dapat memperoleh nilai gamelan sebagai sebuah kompleksitas IPTEK.

\section{Hasil dan Pembahasan}

Memahami sebuah nilai gamelan bukan perkara yang mudah karena nilai intra-ekstra musikal terkontruksi menjadi satu dalam sebuah produk seni. Kemampuan elemennya dalam melakukan adaptasi dengan perkembangan ruang-waktu sehingga untuk mengejewantahkan nilai gamelan memerlukan proses dan waktu yang sangat panjang. Gamelan merupakan tanda konsep-produk yang merepresentasikan perwujudan kompleksitas ilmu pengetahuan berbasis kearifan lokal jenius. nilai pada gamelan yang dimaksudkan adalah relasi intra-ekstra musikal yang mengkontruksinya yang dikategorikan sebagai nilai adiluhung intangibel yang sampai sekarang ini masih menjadi misteri yang ditatar pada kajiankajian berbagai disiplin ilmu pengetahuan.
Pada setiap elemen, konsep nilai saling mempengaruhi dan melengkapi dalam mengkontruksi keterpiaraan sisttem, seperti; organologi, bunyi, embat, laras, pathet, dan wirama. Elemen-elemen tersebut secara sadar-tidak sadar mempunyai kemampuan menginduksi kemapanan ilmu pengetahuan dan teknologi yang ada.

Gamelan sebagai produk instrumen musik sampai saat ini masih terbatas tatarannya dalam sebuah elemennya saja yaitu berupa gending. Pengejewantahan karawitan sebagai konsep-produk musik tidak bisa lepas dari hakekat dasarnya yaitu bunyi yang merupakan sebuah indeks dari musik. Sebagai sebuah indek, bunyi berasal dari vibrasi atau getaran organologi yang diberi perlakuan oleh seseorang dalam hal ini adalah pengrawit. Hal ini memberikan sebuah pemahaman dalam mengejewantahkan karawitan sebagai konsep-produk musik diperlukan sebuah pendekatan berupa ilmu pengetahuan yang tepat, sesuai dengan tanda-tanda pada jati diri karawitan berdasarkan kearifan lokal jenius.

Bunyi sebagai indek dari akibat dari vibrasi dan sebab dari musik memberikan sebuah 
pemahaman bahwa bunyi dalam musik karawitan harus ditatar dalam orde pertama dalam ranah kelimuan fisika, padahal bunyi berkaitan erat dengan elemen-elemen yang mengkontruksi karawitan sebagai konsepproduk musik maka elemen-elemen tersebut harus ditatar dalam uraian ilmu fisika yang menandakan bahwa dalam karawitanologi, terdapat ilmu fundamental yang merupakan pondasi dalam memahami kontruksi bunyi dengan elemen-elemen penyusun karawitan sebagai musik.
Bunyi instrumen gamelan, atau relasi bunyi repertoar gending sebagai esensi dari karawitan bukan hanya sekedar dalam mempunyai nilai berupa ilmu fisika namun bunyi dalam sebuah instrument musik ataupun yang mengkontruksi gending tentu mempunyai makna yang berhubungan dengan latar belakang mindset lokal jenius dalam mentransformasi sebuah konsep bunyi ke dalam wujud instrument ataupun gending. Latar belakang sebuah bunyi yang ada dalam jati diri gamelan mempunyai nilai ilmu sejarah dan psikologi.

. Tabel 1

Nilai Gamelan

\begin{tabular}{|l|l|l|l|}
\hline No & Tanda & $\begin{array}{l}\text { Dimensi, ruang } \\
\text { lingkup ilmu } \\
\text { pengetahuan }\end{array}$ & \multicolumn{1}{|c|}{ Representasi } \\
\hline 1 & $\begin{array}{l}\text { Organologi } \\
\text { 1. Fisika } \\
\text { Gamelan }\end{array}$ & $\begin{array}{l}\text { 2. Kimia } \\
\text { 3. Teknik }\end{array}$ & $\begin{array}{l}\text { Gamelan merupakan seperangkat instrumen yang } \\
\text { mempunyai karekteristik bentuk organologi dan } \\
\text { berfungsi sebagai alat yang menghasilkan bunyi. } \\
\text { Bentuk atau organologi berkaitan dengan empirisme } \\
\text { vibrasi yang merupakan dasar dari bunyi. }\end{array}$ \\
& 4. Musik & $\begin{array}{l}\text { 1. Gamelan secara kontruksi organologi mengandung } \\
\text { nilai berupa ilmu fisika karena oarganologi-akustik } \\
\text { merupakan salah satu wilayah dari ilmu fisika. } \\
\text { Dalam ilmu fisika tanda pada jati diri gamelan di } \\
\text { tatar hampir pada substansi keilmuannya. }\end{array}$ \\
& & 2. Empirisme vibrasi gamelan secara fisis memerlukan \\
\hline
\end{tabular}




\begin{tabular}{|c|c|c|c|}
\hline & & & $\begin{array}{l}\text { sebuah operator yaitu bahasa matematika, sehingga } \\
\text { dalam gamelan terdapat sebuah disiplin ilmu yaitu } \\
\text { matematika. } \\
\text { 3. Logam, non logam instrument gamelan pasti } \\
\text { mempunyai rumus dasar kimia. Misalkan gamelan } \\
\text { terbuat dari perunggu pasti mempunyai unsur } \\
\text { tembaga (Cu) dan seng (Zn) yang secara kimia } \\
\text { mempunyai beberapa sifat dasar yang dapat dikaji }\end{array}$ \\
\hline 2 & $\begin{array}{l}\text { Bunyi atau } \\
\text { akustik }\end{array}$ & $\begin{array}{l}\text { Fisika } \\
\text { Sejarah- } \\
\text { Antropologi } \\
\text { Psikologi }\end{array}$ & $\begin{array}{l}\text { Esensi sebuah musik adalah bunyi, begitu pula esensi } \\
\text { tanda bunyi gamelan yang dikontruksi oleh pengrawit } \\
\text { dengan mempergunakan sistem laras. Bunyi gamelan } \\
\text { sebagai esensi dasar karawitan mempunyai tanda } \\
\text { seperti angka getar atau frekuensi dan amplitudo yang } \\
\text { merepresentasikan. Ilmu fisika: Komponen tanda } \\
\text { seperti angka getar atau frekuensi, amplitudo } \\
\text { merupakan unsur atomistik yang menandakan dan } \\
\text { merepresentasikan sebuah bunyi. Bunyi gamelan secara } \\
\text { mekanika kuantum mampu berposisi sebagai partikel- } \\
\text { gelombang. Sebagai sebuah partikel, bunyi } \\
\text { merepresentasikan diri dalam tataran warna yang dapat } \\
\text { diamati secara visual sedangkan sebagai sebuah } \\
\text { gelombang, bunyi mampu bertansformasi } \\
\text { merepresentasikan dalam tataran energi yang mampu } \\
\text { dirasakan oleh sistem indera yaitu kulit dan telinga. } \\
\text { 1. Sejarah atau antropologi: Lahirnya bunyi gamelan } \\
\text { pasti dimulai dari latar belakang. Dalam berbagai } \\
\text { uraian tulisan yang terdapat dalam pupuh-pupuh } \\
\text { tentang bunyi gamelan seperti dalam prekempa, } \\
\text { centhini bahwa bunyi gamelan berasal dari }\end{array}$ \\
\hline
\end{tabular}




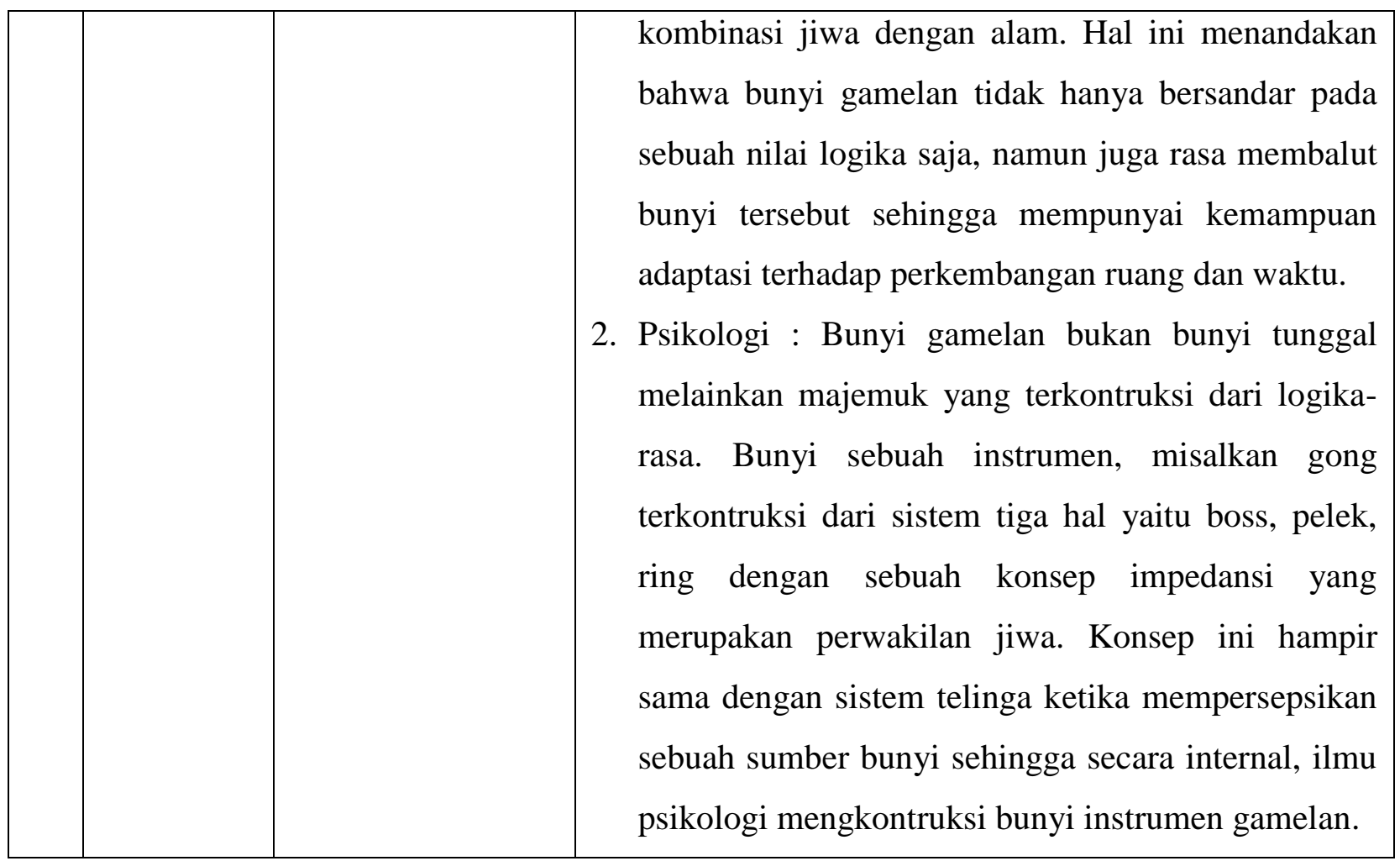

\section{Simpulan}

\begin{tabular}{cccr} 
Nilai & \multicolumn{2}{c}{ gamelandalam } & batasan \\
organologi & akustik & merupakan & konsep \\
kecerdasan & lokal & jenius & dalam
\end{tabular}
mentransformasikan relasi ilmu pengetahuan dan teknologi dalam relasi intra-ekstra musikal sebagai produk dan musik sebagai sebuah perilaku, musik itu sendiri dan teori atau proses kognitif. Gamelan sebagai produk menjadi sebuah perilaku simbolik masyarakat dalam mengkontruksi elemen intra-ekstra musikal yang mempunyai perkembangan terhadap nilai perkembangan gamelan sebagai sebuah proses kognitif

\section{Daftar Pustaka}

Bandem, I. Made . 1986. Prakempa sebuah Lontar Gambelan Bali. Denpasar: Akademi Seni Tari Indonesia Denpasar. 
Becker, Judith; Freinstein, AL (ed) .1984. Karawitan Source Reading in Javanese Gamelan and Vocal Music Volume I. United States of America. Michigan Papers on South an Southeast Asia Center for South and Southeast Asian studies the University Michigan.

Creswell. 2011. Research Design Pendekatan kualitatif, kuantitatif dan mixed terj. Yogyakarta: Pustaka Pelajar

Henley, Jenney. 2012. Good Vibration: Musics and Social Education for Young Offenders: Javanese Gamelan Projects. Institute of Education university London.

Kunst, Jaap. 1949. Music In Java Vol I, II. Martinus Nijhoff, Revised and Enlarged Edition.

Nattiez, Jean. 1990. Music and Discource : Toward a Semiology of Music. New Jersey: Princeton University Press

Oohashi, Tsutomu et.all. 2000. In Audible High Frequency Sound Affect Brain Activity: Hyperconic Effetct. Jurnal Neurophysiology 83: 3548-3558. American Psysiological Society.

Oohashi, Tsutomu et. all. 2002. Multidisiplinary Study on the ypersonic Effect. Volume 1226, Januari 2002, P.27-42. Internacional Congress Series.

Oohashi, Tsutomu et.all. 2006. The Role of Biological System Other than Auditory Air-Conduction the Emergence of the Hypersonic Effect. Volume 1073-1074, 16 Februari 2006. P 339-347. Brain Research.

Pierce, Charles. 1931. Colected Papers of Charles Sanders Pierce. Volume I. united Stated America Harvard College. Cambridge Massachuset.

Sumarsam. 2002. Hayatan Gamelan: Kedalaman Lagu, Teori, dan Perspektif Cetakan I: Surakarta. STSI Press

Supanggah, Rahayu. 2009. Bothekan karawitan II Garap. Surakarta: Program Pascasarjana bekerja sama dengan Institut seni Indonesia Surakarta Press.

Wasisto, Sudarjana, Adhi Susanto. 1969. Penjelidikan angka getar gamelan terkemuka di keraton Solo dan Jogjakarta. Fakultas Teknik Universitas Gadjah Mada. Yogyakarta.

Webtografi:

Menyapa alien dengan musik, termasuk gending Jawa. Senin 17

Oktober 2011. Posted by arum ndalu

Puspawarna tembang Jawa yang diperdengarkan di luar angkasa. 12 juni 2013. Posted by Widiani.

www.Good Vibrations. org 
